\title{
Paternal Engagement of Fathers of Young Children in Kupang
}

\author{
Anamaria Vinansia Sengga, Engelikus Nama Koten, Beatriks Novianti Kiling-Bunga
}

Early Childhood Education Course, Faculty of Teaching and Education, University of Nusa Cendana, Indonesia

Corresponding e-mail: $\underline{\text { ana.sengga@gmail.com }}$

\begin{abstract}
This study aimed to determine the involvement of fathers in paternal engagement dimension in Kupang city. Paternal engagement is a form of direct interaction between child and father shown by the way father take care of his child or nurturing child or a variety of other activities. The study design of this study was descriptive quantitative research, utilized a questionnaire to gather data. Accidental sampling used in recruiting participants. 150 fathers of children aged 0-8 years participated in the study. Research analysis used was descriptive statistics with the help of the Microsoft Office Excel. The results showed that around a third of participants have high level of paternal engagement. Patterns discovered from cross tabulation with several demographic factors also discussed in this article. The result from this study should be confirmed with further research in order to understand the process of engagement in father-child's interaction especially in Kupang city and other rural areas in Indonesia. Improved engagement will help in avoiding child violence and will also contribute in child's development.
\end{abstract}

Keywords: paternal engagement, young children, Kupang

\section{INTRODUCTION}

Parenting is an interaction process conducted by parent in order to support child's development. Involvement in parenting and child's education is a responsibility of parent both mother and father. But throughout history in some communities in the world, father has role of earn a living, protecting family, to educate child and as head of the family. While a mother has role of taking care family, nurturing children, educating and protecting children, and also to earn additional living

(Simasari, 2014).

Social, economy and cultural change have replaced the meaning of involvement in parenting that was dominantly mother's tasks. According to Casper and O'Connell (in Fitriaryanti, 2012), the increase of mother's chance to work, shift in working's hours, availability of flexible work time, availability of part time works, and availability of in-house jobs makes parenting by father becomes more possible, even in a long-term basis. Policies and rules that had more focuses in mother, start to gives chances and also room for fathers to express themselves in parenting process. Father has important contributions for child's development, experience had together with father, will impacted a child to adult time. According to Cabrera (in Hidayati et al., 2011), father's role and parenting behaviours will affect the development and prosperity of child and also the transition phase to teenage stage. Hernandez \& Brown (in Hidayati et al., 2011) said that cognitive and social competency development in a young child is influenced by attachment, emotional relationship and availability of resources provided from his/her father.

In United States, Day and Lamb (in Santrock, 2007) record that there was a major change in father's role in family. During the period of colonialism in United States, parent especially father has responsibility of moral teaching. After industry revolution, the focus of father's role shifted to a role of living earner for family. Approaching 1970, fathers' interest as active and loving parent has risen. They are not only responsible for disciplining and controlling children and earning a living for family, they are also actively involving themselves in parenting children. Father's involvement in paternal engagement dimension is a direct involvement or one on one interaction with child. According to Lamb (in Simasari, 2014; Hidayati et al., 2011; Wahyuningrum, 2011; 
Abdullah, 2009), paternal engagement is a direct contact between father and child through father taking care or nurturing child, and through various joint activities between father and child. Abdullah (2009) said that involvement in child parenting consisting aspects of time, interaction and attention. Involvement is an active participation and has emphasis in repetition. Andayani and Koentjoro (2004) said that a father considered involved in parenting when he initiated to form a bond with his child and make good use of his resources including affection, physical and cognition. Father is the foundation maker of intellectual capabilities, problem solving abilities and other things related with child's cognitive issues. When father with child interacts, and conduct physical contacts either in form of touching or in a game, father could get involved warmly and connect emotionally.

Abdullah's paper (2009) said that mother's role in caretaking and nurturance is more related to physical nurturance and parenting while, father's role is more into playing and adventuring. Father's role is related more in rational side while mother's role is more in emotional side of the child (Astuti \& Puspitarani, 2013). Bond between father, mother and child will have its own benefits, generally mother will play a role of loving and warm figure, while father will help child to explore and conquer challenges. From mother, child will learn tenderness, emotional control and love, while from father child will learn about decisiveness, wisdom, kinaesthetic and cognitive abilities. Father will also help child to be steadfast, competitive, challengeloving and loves to explore (Abdullah, 2009).

In Indonesia, there are a lot of books and articles with parenting themes wanted by young couples. However, the development of father's role in parenting is not known yet, because of lack of research about this topic in Indonesia. Especially more in Eastern Indonesia's culture, traditional tasks of parenting such as feeding, bathing, wearing clothes and so on are like taboo for men. Besides that, our observation in several Early Childhood Education and Development (ECED) posts in Kupang City told us that parent's involvement is dominated by mother instead of father, this shows that more mother is directly involved with child compared to father. Furthermore, mother also involved themselves more in meeting and activities held by the ECED post. As far as we know, there were not any research considering father's involvement in parenting young children, especially in paternal engagement dimension. This research described paternal engagement of fathers in Kupang
City, East Nusa Tenggara province. The results hopefully will help policy makers to formulate appropriate programs to improve paternal parenting in order to support child's development.

\section{METHOD}

This research used quantitative descriptive design. According to Christensen (in Simasari, 2014), descriptive research method is a research that has focus in describing or explaining a phenomenon, activity or situation that is happening. While Gravetter and Forzano (in Simasari, 2014) said that quantitative research is a research based on variable measurement to gain numerical value, that is delivered through statistical analysis to formulate interpretation and conclusion.

Participants in this research are father who lives in Kupang City. Sampling done with nonprobability technique, specifically accidental sampling, where participants are those who met requirements based on research's objective. The participants are fathers of child aged one to eight years old. The measurement tool is a questionnaire we made. Questionnaire made based on blueprint specifically created for this research. Questionnaires given consisted of introduction, filling instructions, personal identity including demographic factors and ten questions to measure paternal engagement. Participants were told to pick their answers whether strongly agree, agree, disagree or strongly disagree.

Results were analysed with descriptive analysis approach that emphasis the analysis to numerical data. Paternal engagement had been clustered to five categories and analysed together with demographic factors. Results from each level will be compared and contrasted with another variant of the demographic factor. Pattern emerged discussed with recent related researches.

\section{RESULT}

This research used paternal engagement questionnaire to measure the level of direct interaction between father and young child. As many as 150 participants participated in this research. The participants were met in one of Kupang City's public park. Table 1 shows some basic statistical info on the research: 
Table 1. Paternal engagement of statistical data

\begin{tabular}{|l|r|}
\hline \multicolumn{2}{|c|}{} \\
\hline Mean & 37.9266666 \\
& 7 \\
Standard Error & 0.48642389 \\
Median & 2 \\
Mode & 38 \\
Standard Deviation & 40 \\
& 5.95745167 \\
Sample Variance & 2 \\
& 35.4912304 \\
Kurtosis & 3 \\
\hline
\end{tabular}

Table 1. Cont.

\begin{tabular}{|l|r|}
\hline Skewness & - \\
Range & 0.229105495 \\
Minimum & 30 \\
Maximum & 20 \\
Sum & 50 \\
Count & 5689 \\
\hline
\end{tabular}

Minus value in skewness shows that data distribution is tilted to the right of normal distribution, while negative kurtosis shows that data distribution has big variance and has sloping distribution.

Table 2. Father's education

\begin{tabular}{|c|c|c|c|c|c|c|c|c|}
\hline \multirow{2}{*}{ Category } & \multicolumn{6}{|c|}{ Education } & \multirow[t]{2}{*}{ Total } & \multirow[t]{2}{*}{ Percentage } \\
\hline & Elementary & Junior high & Senior high & Diploma & Bachelor & Doctoral & & \\
\hline Very high & 2 & 2 & 12 & 1 & 9 & 1 & 27 & 18 \\
\hline High & 1 & 4 & 30 & 3 & 12 & 0 & 50 & 33,3 \\
\hline Average & 4 & 6 & 25 & 2 & 16 & 0 & 53 & 35,3 \\
\hline Low & 3 & 3 & 7 & 0 & 4 & 0 & 17 & 11,3 \\
\hline Very low & 1 & 1 & 0 & 0 & 1 & 0 & 3 & 2 \\
\hline Total & 11 & 16 & 74 & 6 & 42 & 1 & 150 & 100 \\
\hline Percentage & 7,33 & 10,67 & 49,33 & 4 & 28 & 0,67 & 100 & \\
\hline
\end{tabular}

Table 2 above shows the education level of participants. According to the data, the largest percentage of participants $(35,3 \%)$ belongs to average category of paternal engagement, most of them has senior high school level of education. Second largest group was fathers with high level of paternal engagement $(33,3 \%)$, come quite close with the average category group. Very high category comes third (18\%) followed by low category $(11,3 \%)$ and very low category $(2 \%)$. There was more father with very high and high paternal engagement $(51,33 \%)$ compared to very low and low (13,33\%). From total 150 participants, almost $50 \%$ were senior high school graduates, while bachelor came second with total of $28 \%$. It shows that majority of the parents don't have any college degree. Majority of parents with senior high school education have high paternal engagement (30 persons) compared to majority of parents with bachelor education that has average paternal engagement (16 persons).

Table 3. Father's age

\begin{tabular}{ccccccc}
\hline \multirow{2}{*}{ Category } & \multicolumn{2}{c}{ Father's age group } & Total & \multirow{2}{*}{ Percentage } \\
\cline { 2 - 5 } & Youth & Young adult & Middle adult & Old age & & \\
\hline Very high & 1 & 20 & 6 & 0 & 27 & $18 \%$ \\
\hline High & 1 & 39 & 10 & 0 & 50 & $33,3 \%$ \\
\hline Average & 3 & 41 & 9 & 0 & 53 & $35,3 \%$ \\
\hline Low & 0 & 14 & 2 & 1 & 17 & $11,3 \%$ \\
\hline Very low & 0 & 3 & 0 & 0 & 3 & $2 \%$ \\
\hline Total & 5 & 117 & 27 & 1 & 150 & $100 \%$ \\
\hline Percentage & 3,33 & 78 & 18 & 0,67 & 100 & \\
\hline
\end{tabular}


Youth: $18-24$ years old; Young adult: $25-45$ years old; Middle adult: 46 - 59 years old; Old age: 60 years old onwards Fathers involved in this research have age ranged from 22 to 65 years old. There were four groups of age: youth, young adult, middle adult and old age. Majority of participants belonged in young adult age $(78 \%)$, while only one participant $(0,67 \%)$ is in old age. There were more young adult participants with very high and high level of paternal engagement $(39,33 \%)$ compared to very low and low level $(11,33 \%)$. Similar pattern also found in middle adult group, with more participants with very high and high paternal engagement $(10,66 \%)$ than very low and low paternal engagement $(1,33 \%)$. This pattern supported the percentages of parents with very high and high paternal engagement when compared to very low and low level. It is also worthy to notice that there were more middle adult fathers with high paternal engagement (10 persons) compared to other categories, showing that middle adult fathers have tendency of high paternal engagement.

Table 4. Father's job

\section{Job}

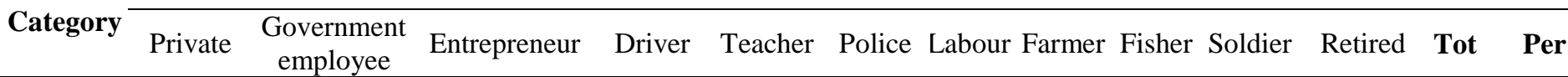

\begin{tabular}{cccccccccccccc}
\hline Very high & 8 & 8 & 3 & 0 & 1 & 2 & 4 & 1 & 0 & 0 & 0 & 27 & 18 \\
\hline High & 10 & 9 & 23 & 2 & 1 & 3 & 0 & 1 & 1 & 0 & 0 & 50 & 33,3 \\
\hline Average & 9 & 10 & 22 & 2 & 0 & 3 & 3 & 0 & 1 & 2 & 1 & 53 & 35,3 \\
\hline Low & 3 & 4 & 4 & 0 & 0 & 1 & 1 & 0 & 3 & 0 & 1 & 17 & 11,3 \\
\hline Very low & 0 & 1 & 0 & 1 & 0 & 0 & 0 & 0 & 1 & 0 & 0 & 3 & 2 \\
\hline Total & 30 & 32 & 52 & 5 & 2 & 9 & 8 & 2 & 6 & 2 & 2 & 0 & 100 \\
\hline Percentage & 20 & 21,3 & 34,7 & 3,3 & 1,3 & 6 & 5,3 & 1,3 & 4 & 1,3 & 1,3 & 100 \\
\hline
\end{tabular}

Table 4 above shows data related participants' jobs with total 11 jobs ranged from government employee to retired person, majority of participants works as entrepreneur $(34,7 \%)$, followed by government employees $(21,3 \%)$, private employees (20\%), police (6\%) and labour $(5,3 \%)$. The other six jobs each has less than five percent's participants. There were more entrepreneur and private employee fathers with high paternal engagement compared to other

categories. This shows that father who works as private employee and entrepreneur has tendency of high level paternal engagement.

Table 5. Father's ethnicity

\begin{tabular}{|c|c|c|c|c|c|c|c|c|c|c|c|c|c|c|c|}
\hline \multirow[b]{2}{*}{ Category } & \multicolumn{13}{|c|}{ Ethnicity } & \multirow[b]{2}{*}{ Total } & \multirow{2}{*}{$\begin{array}{l}\text { Percent } \\
\text { age }\end{array}$} \\
\hline & Alor & Timor & Rote & Flores & $\overline{\text { Sumba }}$ & $\begin{array}{c}\text { Sumbaw } \\
\text { a }\end{array}$ & Semau & $\begin{array}{c}\mathrm{Bi} \\
\mathrm{ma}\end{array}$ & $\begin{array}{c}\text { Bat } \\
\text { ak }\end{array}$ & Bugis & $\begin{array}{l}\text { Timor } \\
\text { Leste }\end{array}$ & Jawa & Ambon & & \\
\hline Very high & 1 & 9 & 4 & 9 & 0 & 0 & 0 & 1 & 0 & 0 & 1 & 0 & 2 & 27 & 18 \\
\hline High & 5 & 19 & 5 & 12 & 1 & 0 & 1 & 0 & 2 & 1 & 1 & 1 & 2 & 50 & 33,3 \\
\hline Average & 3 & 25 & 5 & 10 & 2 & 1 & 0 & 1 & 2 & 1 & 0 & 3 & 0 & 53 & 35,3 \\
\hline Low & 5 & 5 & 1 & 2 & 1 & 0 & 0 & 0 & 0 & 1 & 0 & 2 & 0 & 17 & 11,3 \\
\hline Very low & 2 & 1 & 0 & 0 & 0 & 0 & 0 & 0 & 0 & 0 & 0 & 0 & 0 & 3 & 2 \\
\hline Total & 16 & 59 & 15 & 33 & 4 & 1 & 1 & 2 & 4 & 3 & 2 & 6 & 4 & 150 & 100 \\
\hline $\begin{array}{c}\text { Percentage } \\
\text { s }\end{array}$ & 10,66 & 39,33 & 10 & 22 & 2,66 & 0,67 & 0,67 & 1,3 & 2,6 & 2 & 1,3 & 4 & 2,66 & 100 & \\
\hline
\end{tabular}


There were total of 13 ethnicities involved in this research. Largest ethnicity was Timor with 59 persons $(39,3 \%)$, followed by Flores with 33 persons (22\%), Alor with 16 persons (10,66\%), and Rote with 16 persons $(10 \%)$. The other nine ethnicities each has less than five percent's participant. Flores has more participants with high level of paternal engagement (12 persons) compared to very high, average, low and very low category. Interestingly Allor's has same number between participants with high paternal engagement and low paternal engagement ( 5 persons). Majority of Timor participants has average level of paternal engagement.

Table 6. Child's birth order

\begin{tabular}{cccccccc}
\hline \multirow{2}{*}{ Category } & \multicolumn{9}{c}{ Birth order } & & Total & Percentage \\
\cline { 2 - 5 } & First-born & Middle & Last-born & Only child & & \\
\hline Very high & 6 & 10 & 7 & 4 & 27 & 18 \\
\hline High & 12 & 7 & 20 & 11 & 50 & 33,3 \\
\hline Average & 10 & 11 & 22 & 10 & 53 & 35,3 \\
\hline Low & 4 & 2 & 9 & 2 & 17 & 11,3 \\
\hline Very low & 0 & 1 & 2 & 0 & 3 & 2 \\
\hline Total & 32 & 31 & 60 & 27 & 150 & 100 \\
\hline Percentages & 21,33 & 20,66 & 40 & 18 & 100 & \\
\hline
\end{tabular}

Table 6 describes level of paternal engagement when cross tabulated with birth order data. There were four orders, first-born, middle, last-born and only child. $40 \%$ of the participants have last-born young child, while $21,33 \%$ have first-born young child, closely followed by participants who have middle young child with $20,66 \%$. Participants with only child who's still young make up $18 \%$ of total participants. 10 out of 31 participants with middle child have very high paternal engagement, come second after 11 participants with average paternal engagement.

\section{DISCUSSION}

Success in child's development will depend on parents' role. Both father and mother has important role in parenting with challenging tasks. Especially when a child still in young age, parent has a role with significant contribution to the shaping of child's behaviour and personality. This research described the direct interaction between father and his young child or also called paternal engagement by Lamb (in Abdullah, 2009), in Kupang City. The participants were 150 fathers with child aged between one to eight years old. The results show that around $35,3 \%$ of participants have average paternal engagement, closely followed by a third of participants with high paternal engagement. There more father with very high and high paternal engagement compared to very low and low level.

This number shows us that fathers of young children in Kupang City have average to high level of paternal engagement. This is promising considering that in other region in East Nusa Tenggara province, there were still many instances of child violence (Kiling \& Bunga 2014a; Kiling \& Bunga, 2014b). Kupang could serves as important role model or benchmark for other districts in East Nusa Tenggara province, so that fathers in other region too could have high paternal engagement and low number of violence child cases. Of course, there is a probability of social desirability factor that could affect participants in filling our questionnaire with desirable answers.

Cross tabulation with father's level of education revealed to us that fathers with senior high school level of education tends to have higher paternal engagement level compared to fathers with bachelor level of education. This indicates that high level of education doesn't instantly translated to higher level of direct interaction with child, and low level of education will surely affect the interaction father and child (Saleh et al., in $\mathrm{Wu}, 2009$ ). This might be due to various other factors that affected father's quality of parenting interaction, for example the interest of parents in gathering information concerning parenting (Margolin, in Sukadji, 1988). Further study needed to check on this matter. 
Pattern emerged from data concerning father's age and paternal engagement was that more middle adult fathers tends to have high paternal engagement. More age in life might play important in this, as middle age people have more wisdom and also calmer in facing life situations. They also have more stable career that could influence harmony in family (Whaley \& Wong, 1991; Heath, in Wu, 2009). More than three-quarters of participants belonged in young adult group that is still productive and also could be a good target for parenting program from government and other stakeholders.

This research also found that father with job as private employee and entrepreneur tends to have high paternal engagement compared to other jobs available. Shapiro (2003) said that financial responsibility belongs to fathers and by fulfilling that responsibility, they have difficulties to spend more time with their children. This is not true for father who works as private employee and entrepreneur. Private employee could give flexibility in work and more chance in promotion and self-actualisation as opposed to other jobs such as government employee. Entrepreneur of course has even more flexibility in work condition and time that could help father to spend more time with their family.

Fathers from Flores tends to have higher level of paternal engagement compared to father from Timor whose proportion are the largest in this study with more than a third $(39,3 \%)$ of total participants. This shown that Hammer and Turner (in Kurniawan, 2013) and Bronte-Tinkew and Moore (2004) were right about every ethnicity has unique and different beliefs and parenting practices. Stakeholders could learn more from parenting practices of ethnicity with high level of paternal engagement and target other ethnicities with low or average level of paternal engagement with appropriate community intervention especially concerning parenting awareness and skills.

Parents whose young child is middle child tends to have very high paternal engagement. This is supported by Andayani and Koentjoro (2004) who argued that parents will have more experience and skills in parenting and nurturing second child or middle child, and youngest child. First-born usually will get mixed parenting practices and effects since parents are still adjusting and learning how to- in parenting. All of these descriptive findings should be explored further using more advanced inferential statistic technique or qualitative approach. Confirming these findings could help in deciding which programs that is effective for improving parenting especially paternal engagement in Kupang and other rural areas in Indonesia.

\section{CONCLUSIONS}

Paternal engagement was discovered average too high in fathers of young children in Kupang City. This finding needed to be confirmed by qualitative research to discover dynamics beyond the direct interaction between fathers and young children. Several patterns discussed in this research could be considered in policy making process, especially by related government and non-government institutions' programs. Fathers need to keep their level of paternal engagement by continuously seeking new information concerning parenting. Mothers also need to support their husband in parenting by complementing and helping in financial aspect whenever they could.

\section{REFERENCES}

Abdullah, S.M. (2009). Keterlibatan Ayah (Paternal Involvement) Dalam Pengasuhan Anak (Sebuah Kajian Teoritis). Paper. Universitas Mercu Buana Yogyakarta.

Andayani, B., \& Koentjoro. (2004). Psikologi keluarga: Peran ayah menuju coparenting. Surabaya: CV Citra Media.

Astuti, V., \& Puspitarani, P. (2013). Keterlibatan Ayah Dalam Pengasuhan Jarak Jauh Remaja. Prosiding Seminar Nasional Parenting 2013. Hal 121-131.

Bronte-Tinkew, J., Moore, J.A., Halle, T. (2004). The Developing a Daddy Survey (DADS) Project and The Collaborative Work of the DADS Working Group. Child Trends.

Fitriaryanti. (2012). Ayah Forgotten Contributors to Children Development. Accessed in 23 November 2015 from http://fitriaryanti.wordpress.com/2012/08/05/a yah-forgotten-contributors-to-childrendevelopment/

Hidayati, F., Kaloeti, D. V. S., \& Karyono, K. (2011). Peran Ayah dalam Pengasuhan Anak . Jurnal Psikologi Undip, 9(1), 1-10.

Kiling, I. Y., \& Bunga, B. N. (2014a). Urgensi positive parenting di Sumba Timur. In Taufiqurrahman, A. Puspitacandri, H. Khotimah, \& U. Manara (Eds.), Proceeding Seminar Nasional dan Call for Paper Ketahanan Keluarga sebagai Aset Bangsa: Family, Marriage, Parenting. "Pengelolaan 
Mutu Keluarga dan Perkawinan untuk Persiapan Generasi Muda Berkualitas” (pp. 836-848). Malang: Unmer Press.

Kiling, I. Y., \& Bunga, B. N. (2014b).

Kompleksitas kekerasan kepada anak perempuan kasta Ata di Sumba Timur. In P. Satwiko, \& D. Listiorini (Eds.), Proceeding Senanti 2014 (pp. 63-67). Yogyakarta: Universitas Atma Jaya Yogyakarta.

Santrock, J.W. (2007). Child Development: an introduction: 11th edition. New York: McGraw-Hill Companies, Inc.

Shapiro, J. L. (2003). The Good Father (Terjemahan dari The Measure of a Man: Becoming the Father You Wish Your Father Had Been). Bandung: Penerbit Kaifa.

Simasari, G. R. (2014). Studi Deskriptif Mengenai Keterlibatan Ayah Dalam

Pemenuhan Tugas Perkembangan Anak Pada Keluarga Di Tahap

Family With Preschool Children. Paper.

Universitas Padjadjaran. Accessed from http://pustaka.unpad.ac.id/wpcontent/uploads/2015/02/Ghea.pdf

Sukadji, S. (1988). Keluarga dan Keberhasilan Pendidikan. Depok: URDAT Fakultas Psikologi Universitas Indonesia.

1.1.1 Kurniawan, T. (2013). Kampanye Sosial Pentingnya Peran Ayah Dalam Mempengaruhi Perilaku Anak. Paper. Perpustakaan UNIKOM, Bandung. Accessed from http://elib.unikom.ac.id/files/disk1/639/jbptuni kompp-gdl-tonykurnia-31933-11-unikom_ti.pdf

Wahyuningrum, E. (2011). Peran Ayah (Fathering) dalam Pengasuhan Anak Usia Dini (sebuah kajian teoritis). Psikowacana, 10(1\&2), 1-19.

Whaley, L. F., and Wong, D. L. (1991). Nursing Care infants and children Fourth Edition. Toronto: Mosby Year Book.

Wu, L. E. (2009). Father Involvement in Chinese American Families and Children's SocioEmotional Development. Thesis. Sacramento: California State University 